\title{
IMPLEMENTASI PENGEMBANGAN KARIER APARATUR SIPIL NEGARA DI ERA OTONOMI DAERAH
}

\author{
Rethorika Berthanila \\ Program Studi Administrasi Publik \\ Fakultas Ilmu Sosial Ilmu Politik dan Ilmu Hukum \\ Universitas Serang Raya \\ E-mail. rethorikaberthanila@gmail.com
}

\begin{abstract}
Abstrak
Penelitian ini bertujuan untuk mengetahui bagaimana implementasi pengembangan karier Aparatur Sipil Negara di kantor Linkungan Hidup Pandeglang. Metode penelitian yang digunakan kuantitatif deskriptif. Instrument dalam penelitian ini berbentuk kuesioner, teknik pengumpulan observasi dan studi kepustakaan. Teknik sampling yang digunakan sampel jenuh. Teknik analisis data yang digunakan dalam penelitian ini adalah statistik deskriptif yaitu pengujian $t$ test satu sampel. Pengujian validitas instrument dengan menggunakan rumus korelasi product moment dan pengujian reliabilitas instrument dilakukan dengan internal konsistensi dengan menggunakan teknik belah dua. Hasil penelitian dan penghitungan serta pengujian hipotesis, maka dapat diketahui Implementasi pengembangan karier Aparatur Sipil Negara di Kantor Lingkungan Hidup Kabupaten Pandeglang, tercapai 73,31\% dari maksimal 70\% yang diharapkan. Pengujian hipotesis yang dilakukan berdasarkan uji hipotesis pihak kiri menunjukkan bahwa Ho ditolak dan Ha diterima, yang berarti implementasi pengembangan karier Aparatur Sipil Negara di Kantor Lingkungan Hidup Kabupaten Pandeglang adalah sudah baik dilaksanakan karena mencapai 73,31\%. namun masih ada kendala dalam pelaksanannya.
\end{abstract}

Kata Kunci : Implementasi, Pengembangan karir

\begin{abstract}
This study aims to determine how the career development of the State Civil Apparatus is implemented in the Pandeglang Living Environment office. The research method used is quantitative descriptive. The instrument in this study is in the form of a questionnaire, observation collection techniques and library studies. The sampling technique used is saturated samples. The data analysis technique used in this study is descriptive statistics, namely testing one sample t test. As for testing the validity of the instrument by using the product moment correlation formula and instrument reliability testing is done with internal consistency using the split technique. The results of research and calculations and hypothesis testing, it can be seen that the implementation of career development of the State Civil Apparatus in the Office of Environment Pandeglang Regency, reached $73.31 \%$ of the maximum 70\% expected. Hypothesis testing based on the left hypothesis testing shows that Ho is rejected and Ha is accepted, which means that the implementation of the career development of the State Civil Apparatus in the Office of Environment of Pandeglang Regency is already well implemented because it reaches $73.31 \%$. but there are still obstacles in the implementation.
\end{abstract}

Keywords: Implementation, Career Development 


\section{A. PENDAHULUAN}

Menurut UU RI Nomor 5 Tahun 2014 Tentang Aparatur Sipil Negara (ASN) menjelaskan penegrtian dari ASN adalah profesi bagi Apartatur Sipin Negara dan pegawai pemerintah dengan perjanjian kerja yang bekerja pada instansi pemerintah. Jenis, status, dan kedudukan ASN terdiri atas : Pegawai ASN terdiri atas PNS yang merupakan pegawai ASN yang diangkat sebagai pegawai tetap oleh Pejabat Pembina Kepegawaian dan memiliki nomor induk pegawai secara nasional dan PPPK merupakan pegawai ASN yang diangkat sebagai pegawai dengan perjanjian kerja oleh Pejabat Pembina Kepegawaian sesuai dengan kebutuhan instansi pemerintah dan ketentuan UndangUndang, Pegawai ASN berkedudukan sebagai unsur aparatur Negara, Pegawai ASN melaksanakan kebijakan yang ditetapkan oleh pimpinan Instansi Pemerintah, Pegawai ASN harus bebas dari pengaruh dan intervensi semua golongan dan partai politk

Di era otonomi daerah seiring dengan era reformasi, ada kecenderungan kebijakan pengembangan karier pegawai dikaitkan dengan kebijakan politik. Sehingga seseorang menduduki suatu jabatan hanya karena akses politik dan kurang memiliki kompetensi dalam jabatan, prinsip profesionalisme, prestasi kerja dan regenerasi. Hal ini tidak sesuai kebjakan pemerintah yang menyatakan bahwa suatu jabatan dilaksanakan berdasarkan prinsip profesionalisme sesuai dengan kompetensi, prestasi kerja dan jenjang pangkat yang ditetapkan untuk jabatan itu serta syarat objektif lainnya tanpa membedakan jenis kelamin, suku, agama, ras atau golongan.
Setiap pegawai baik itu pegawai swasta maupun pegawai pemerintahan dimanapun mereka bekerja tentu akan selalu mengharapkan atau mendambakan suatu perbaikan dan peningkatan serta kemajuan dalam pekerjaannya. Hal ini berarti bahwa setiap pegawai ingin selalu memiliki karier yang sedemikian baik sehingga selama masa bekerja, pegawai tersebut dapat menduduki suatu kedudukan atau jabatan yang lebih tinggi sesuai dengan kemampuan dan prestasi yang dimiliki, yang tentunya hal ini mengandung pengertian bahwa ia siap memikul beban dan tanggung jawab yang lebih besar dan tentunya mengharapkan penghasilan yang lebih besar pula.

Peningkatan karier seorang pegawai tidak akan terjadi dengan sendirinya karena keberhasilan karier pegawai memerlukan perencanaan dan pengembangan dalam pelaksanaannya. Berdasarkan kenyataan bahwa pengalaman dapat memberikan pegawai akan tanggung jawab dalam merencanakan dan mengembangkan kariernya sebagaimana yang diharapkan, sehingga peningkatan karier tergantung dari kesiapan pegawai yang bersangkutan dalam melaksanakan rencana-rencana yang telah disusunnya guna pengembangan kariernya.

Kemampuan pegawai dapat membantu dalam menentukan dan merencanakan pengembangan dan peningkatan kariernya. Dalam pelaksanaan kerja, seorang pegawai perlu menampilkan semua kemampuan dan produktivitas kerja yang dimiliki, disamping itu pula, pegawai perlu juga menunjukkan suatu perilaku yang positif dalam berpikir dan bersikap. Untuk itu 
pegawai perlu juga menunjukkan kemampuannya dalam pengembangan produktivitas kerja serta pegawai selalu sigap dalam memanfaatkan semua kesempatan yang tersedia untuk pengembangan kariernya.

Dalam rangka pengembangan karir dan penempatan dalam jabatan, seorang pemimpin harus dapat mengembangkan potensi optimal bawahannya, serta secara tepat dan benar menilai kesiapan dan kemampuan bawahan, sehingga proses pengangkatan dan penempatan dalam jabatan betulbetul menganut merit system, yaitu berdasarkan kecakapan, kemampuan atau keahlian tertentu sesuai dengan tingkatan jabatannya. Hal ini nampak pada kondisi pada Kantor Lingkungan Hidup Kabupaten Pandeglang dimana belum adanya kriteria yang jelas untuk menempatkan seseorang pegawai dalam jabatan.

Berdasarkan hasil pengamatan yang penulis lakukan, menunjukkan bahwa pelaksanaan pengembangan karier pada era otonomi daerah masih mencapai $70 \%$ yang pelaksanaannya sesuai dengan ketentuan yang telah ditetapkan. Hal ini terindikasi dari hal-hal sebagai berikut : masih adanya pengangkatan pegawai untuk menduduki jabatan-jabatan tertentu kurang didasarkan atas kemampuan dan prestasi kerja pegawai tersebut, tetapi cenderung dilaksanakan atas dasar suka tidak sukanya pimpinan dengan pegawai tersebut, masih adanya pegawai yang menduduki jabatan dalam pos-pos tertentu diberikan kepada pegawai orang-orang yang mempunyai hubungan dengan kekuasaan. Adapun rumusan yang peneliti kemukakan adalah "Seberapa besar Implementasi
Pengembangan Karier Aparatur Sipil Negara Di Kantor Linkungan Hidup Pandeglang?".

\section{Pengertian Implementasi}

Menurut Nurdin Usman (2002 :

70) : Implementasi adalah bermuara pada aktivitas, aksi, tindakan, atau adanya mekanisme suatu sistem. Implementasi bukan sekedar aktivitas, tetapi suatu kegiatan yang terencana dan untuk mencapai tujuan kegiatan. Implementasi adalah bukan sekedar aktivitas, tetapi suatu kegiatan yang terencana dan dilakukan secara sungguhsungguh berdasarkan acuan norma tertentu untuk mencapai tujuan kegiatan. Oleh karena itu implementasi tidak berdiri sendiri tetapi dipengaruhi oleh objek berikutnya.

Menurut Guntur Setiawan (2004 : 39 ) : Implementasi adalah perluasan aktivitas yang saling menyesuaikan proses interaksi antara tujuan dan tindakan untuk mencapainya serta memerlukan jaringan pelaksana, birokrasi yang efektif." Dapat dikatakan bahwa implementasi yaitu merupakan proses untuk melaksanakan ide, proses atau seperangkat aktivitas baru dengan harapan orang lain dapat menerima dan melakukan penyesuaian dalam tubuh birokrasi demi terciptanya suatu tujuan yang bisa tercapai dengan jaringan pelaksana yang bisa dipercaya. Hanifah Harsono (2002 : 67 ) mengemukakan pendapatnya mengenai implementasi atau pelaksanaan sebagai berikut : "Implementasi adalah suatu proses untuk melaksanakan kebijakan menjadi tindakan kebijakan dari politik ke dalam administrasi. Pengembangan kebijakan 
dalam rangka penyempurnaan suatu program.

\section{Pengertian Pengembangan Karir}

Dalam praktek pengembangan karir lebih merupakan suatu pelaksanaan rencana karir seperti yang diungkapkan oleh Handoko (2008:123) bahwa, pengembangan karir adalah peningkatanpeningkatan pribadi yang dilakukan seseorang untuk mencapai suatu rencana karir. Pengembangan karir adalah suatu usaha untuk meningkatkan kemampuan teknis, teoritis, konseptual dan moral karyawan sesuai dengan kebutuhan pekerjaan/jabatan melalui pendidikan dan latihan (Hasibuan, Malayu SP, 2009:69). Simamora (2008: 289) Pengembangan karir sebagai berikut : Pengembangan karir meliputi manajemen karir dan perencanaan karir. Perencanaan karir adalah proses yang dilalui oleh individu karyawan untuk mengidentifikasikan dan mengambil langkah-langkah untuk mencapai tujuan karirnya. Manajemen karir adalah proses yang dilakukan oleh organisasi untuk memilih, menilai, menugaskan, dan mengembangkan para karyawannya guna menyediakan suatu kumpulan orang-orang kompeten untuk memenuhi kebutuhan dimasa depan. Pengembangan karir atau Career Development adalah suatu kondisi yang menunjukkan adanya peningkatanpeningkatan status seseorang dalam suatu organisasi dalam jalur karir yang telah ditetapkan dalam organisasi yang bersangkutan. Handoko (2008:126) tujuan dari pengembangan karir adalah : (a) Untuk mengembangkan para karyawan agar dapat dipromosikan; (b). Untuk mengungkapkan potensi karyawan;(c) Untuk mendorong pertumbuhan; (d) Untuk mengurangi penimbunan (e) Untuk memuaskan kebutuhan karyawan (f) Untuk meningkatkan karir. Menurut Handoko (2008:131) ada beberapa kegiatan pengembangan karir individual yaitu:(a).Prestasi kerja; (b) Exposure (c) Permintaan berhenti (d) Kesetiaan organisional; (e) Mentors dan sponsors; (f) Kesempatan-kesempatan untuk tumbuh.

\section{Faktor-faktor Pengembangan karir}

Menurut Siagian (2007:207), berbagai faktor yang perlu dipertimbangkan adalah sebagai berikut: (a) Perlakuan yang adil dalam berkarir. Apabila kriteria promosi didasarkan pada pertimbangan-pertimbangan yang objektif, rasional dan diketahui secara luas dikalangan pegawai; (b) Keperdulian para atasan langsung. Salah satu bentuk keperdulian itu adalah memberikan umpan balik kepada para pegawai tentang pelaksanaan tugas masing-masing sehingga para pegawai tersebut mengetahui potensi yang perlu diatasi; (c). Informasi tentang berbagai peluang promosi. Akses ini sangat penting terutama apabila lowongan yang tersedia diisi melalui proses seleksi internal yang sifatnya kompetitif. Jika akses demikian tidak ada atau sangat terbatas para pekerja akan mudah beranggapan bahwa prinsip keadilan dan kesamaan dan kesempatan untuk dipertimbangkan,untuk dipromosikan tidak diterapkan dalam organisai; (d). Minat untuk dipromosikan. Menumbuhkan minat para pekerja untuk pengembangan karir ialah pendekatan yang fleksibel dan proaktif. Artinya, minat untuk mengembangkan karir 
sangat individualistik sifatnya. Seorang pekerja memperhitungkan berbagai faktor seperti usia, jenis kelamin, jenis dan sifat pekerjaan sekarang. Pendidikan dan pelatihan yang ditempuh, jumlah tanggungan dan berbagai variabel lainnya. Berbagai faktor tersebut dapat berakibat pada besarnya minat sesorang mengembangkan karirnya; (e) Tingkat kepuasaan. Termasuk dalam meniti karir, ukuran keberhasilan yang digunakan memang berbeda-beda. Perbedaan tersebut merupakan akibat tingkat kepuasaan dalam konteks terakhir tidak selalu berarti keberhasilan mencapai posisi yang tinggi dalam organisasi, melainkan pula berarti bersedia menerima kenyataan bahwa, karena berbagai faktor pembatasan yang dihadapi oleh seseorang, pekerja"puas"apabila ia dapat mencapai tingkat tertentu dalam karir nya meskipun tidak banyak anak tangga karir yang berhasil dinaikinya. Tegasnya, seseorang bisa puas karena mengetahui bahwa apa yang dicapainya itu sudah merupakan hasil yang maksimal dan berusaha mencapai anak tangga yang lebih tinggi akan merupakan usaha yang sia-sia karena mustahil untuk dicapai.

\section{Manfaat Pengembangan karir}

Siagian (2007:210) diantara sekian banyak manfaat yang ambil oleh organisasi, ada lima manfaat yang sering mendapat sorotan utama, sebagai berikut: (a) Pengembangan karir memberikan petunjuk tentang siapa diantara pekerja yang wajar dan pantas untuk dipromosikan dimasa depan; (b) Perhatian yang lebih besar dari bagian kepegawaian terhadap pengembangan karir para anggota organisasi menumbuhkan loyalitas yang lebih tinggi dan komitmen organisasional yang lebih besar di kalangan pegawai, (c). Telah umum dimaklumi bahwa dalam diri setiap orang masih terdapat reservoir kemampuan yang perlu dikembangkan agar merubah sifatnya dari potensi menjadi kekuatan nyata. (d) Perencanaan karir mendorong para pekerja untuk bertumbuh dan berkembang, tidak hanya secara mental intelektual, akan tetapi juga dalam arti professional. (e) Perencanaan karir dapat mencegah terjadinya penumpukan tenaga-tenaga yang terhalang pengembangan karirnya hanya karena atasan langsung mereka.

Untuk menyelenggarakan otonomi daerah yang luas, nyata dan bertanggungjawab diperlukan kewenangan dan kemampuan dalam menggali sumber keuangan sendiri yang didukung oleh perimbangan keuangan antara pusat dan daerah. Dalam hal ini kewenangan keuangan yang melekat pada setiap pemerintahan menjadi kewenangan pemerintah daerah. Dalam menjamin terselenggranya otonomi daerah yang semakin mantap, maka diperlukan kemampuan untuk meningkatkan kemampuan keuangan sendiri yakni dengan upaya peningkatan PAD, baik dengan meningkatkan penerimaan sumber PAD yang sudah ada maupun dengan penggalian sumber PAD yang baru sesuai dengan ketentuan yang ada serta memperhatikan kondisi dan potensi ekonomi masyarakat. Dalam melaksanakan upaya peningkatan PAD, perlu diadakan analisis potensi PAD. 


\section{B. METODE PENELITIAN}

Metode yang penulis gunakan dalam penelitian ini adalah metode survey dengan taraf penjelasan asosiatif kausal yaitu suatu cara penelitian dengan mengumpulkan pendapat dari para responden yang dianggap representatif guna mengungkapkan pengaruh implementasi pengembangan karir Aparatur Sipil Negara pada era otonomi otonomi daerah.

\section{Objek Penelitian}

Populasi adalah wilayah generalisasi yang terdiri dari subyek yang mempunyai kuantitas dan karakteristik tertentu yang ditetapkan oleh peneliti untuk dipelajari dan ditarik kesimpulan. (Sugiyono, 2007 : 90). Populasi dalam penelitian ini terdiri dari :

Tabel 1. Populasi

\begin{tabular}{|c|c|c|}
\hline No & Uraian & Jumlah \\
\hline 1 & Kepala Kantor & 1 \\
\hline 2 & Kasubah Tata Usaha & 1 \\
\hline 3 & Kasie & 3 \\
\hline 4 & Staf pelaksana & 20 \\
\hline \multicolumn{2}{|c|}{ Jumlah } & 25 \\
\hline
\end{tabular}

\section{Teknik Pengumpulan Data}

Teknik pengumpulan data yang penulis pergunakan adalah sebagai berikut: (1) Studi Kepustakaan, (2) Studi Lapangan, yaitu teknik pengumpulan data, meliputi observasi non partisipatifdan Angket tertutup.

Skala pengukuran yang digunakan adalah Skala Likert yang digunakan untuk mengukur sikap, pendapat, dan persepsi sosial seseorang atau sekelompok orang tentang fenomena sosial (Sugiyono 2007 : 107). Data angket berupa data kualitatif, maka perlu dirubah menjadi data kuantitatif dengan menggunakan simbol berupa angka. Untuk setiap item pertanyaan diberi skor satu sampai dengan empat (Skala Likert).

\section{Teknik Analisis Data}

Teknik analisis data dinaksudkan untuk menguji hipotesis yang diajukan.
Teknik analisis yang digunakan untuk maksud tersebut adalah sebagai berikut :

\section{Uji Validitas}

Perhitungan uji validitas dengan menggunakan program SPSS 15 yaitu Korelasi Bivariate Peasrson (Produck Moment Pearson). Dengan ketentuan kriteria pengujiannya dengan taraf signifikasi $5 \%$ atau 0,05 yaitu $r_{\text {hitung }} \geq \mathrm{r}$ tabel, maka instrumen peryataanpernyataan kuesioner berkorelasi terhadap skor total dinyatakan valid, dan jika $\mathrm{r}_{\text {hitung }}<\mathrm{r}_{\text {tabel }}$, maka pernyataanpernyataan dalam kuesioner tidak valid.

\section{Uji Reliabilitas}

Pengujian reabilitas instrumen dalam penelitian ini menggunakan insternal consistency dengan teknik belah dua (spilt half), dari Spearmen Brown, sebagai berikut : 
$\mathrm{r}_{1}=\frac{2 . r_{b}}{1+r_{b}}$ (Sugiyono, $\left.2004: 269\right)$

Dimana :

$\mathrm{r}_{1}=$ Reabilitas internal seluruh instrumen.

$\mathrm{r}_{\mathrm{b}}=$ Korelasi antara belahan

pertama dan kedua

\section{Analisis Rata-rata Penafsiran}

Untuk mengetahui penafsiran implementasi pengembangan karir Aparatur Sipil Negara di Lingkungan Hidup Kabupaten Pandeglang, penulis menggunakan rumus perhitungan dari Sanford Labovitz yang dikutip Bakri Siregar (2000 : 13) yakni sebagai berikut

$$
\mathrm{M}=\frac{\sum f(X)}{n}
$$

Keterangan :

$$
\mathrm{M}=\text { Perolehan angkan penafsiran }
$$

$\mathrm{f} \quad=$ Frekuensi

$\mathrm{x}=$ Pembobotan

$\mathrm{n}=$ Jumlah responden

Kemudian nilai rata-rata tersebut di interpretasikan atas lima kriteria dengan menggunakan skala interval sebagaimana J. Supranto (2000 : 65) yang mengemukakan sebagai berikut :

Skala Interval $=$

JumlahAlternatifJawaban - 1

JumlahSkalaIntervalYangDiinginkan

$$
\begin{aligned}
& \frac{4-1}{4} \\
& \frac{3}{4}=0.75
\end{aligned}
$$

Maka keempat kriteria penafsiran tersebut diperoleh sebagai berikut : a. Jika nilai antara $1,00-1.75$ berarti kriteria penilaian sangat rendah (Sangat Tidak Baik). b.Jika nilai antara 1,76 -
2.50 berarti kriteria penilaian rendah (Tidak Baik).c. Jika nilai antara 2,51 3.25 berarti kriteria penilaian penilaian tinggi (Baik).d. Jika nilai antara 3,26 4.00 berarti kriteria penilaian sangat tinggi (Sangat Baik).

\section{Uji Hipotesis}

Uji hipotesis digunakan untuk menguji hipotesis dalam penelitian ini. Untuk menguji kebenaran hipotesis tersebut, perlu dilaku uji t-test satu sampel dengan menggunakan rumus :

$$
\mathrm{t}=\frac{X-\mu_{0}}{\frac{s}{\sqrt{n}}}
$$

Dimana :

$$
\begin{aligned}
& \mathrm{t}=\text { nilai } \mathrm{t} \text { yang dihitung } \\
& \mathrm{X}=\text { nilai rata }- \text { rata } \\
& \mu 0=\text { nilai yang dihipotesiskan } \\
& \mathrm{S}=\text { simpangan baku sampel } \\
& \mathrm{n}=\text { jumlah anggota sampel }
\end{aligned}
$$

Dengan ketentuan sebaga berkut :

1. Bila $\mathrm{t}_{\text {Hitung }}<\mathrm{t}_{\text {Tabel }}$, maka Ho diterima dan Ha ditolak, dan

2. Bila $\mathrm{t}_{\text {Hitung }}>\mathrm{t}_{\text {Tabel }}$, , maka Ho ditolak dan Ha diterima

\section{HASIL DAN PEMBAHASAN}

Sebelum melakukan analisa data penulis melaukan uji validitas, reliabilitas dan normalitas instrumen dengan hasil sebagai berikut :

\section{Uji Validitas}

Untuk mengetahui apakah angket yang diberikan kepada responden benarbenar dapat mengukur apa yang sedang diukur, maka harus dilakukan pengujian tingkat validitas, jumlah angket yang diterima peneliti sebanyak 16 pertanyaan, kemudian angket yang terkumpul 
diperiksa dan diberi skor kemudian dilanjutkan dengan uji validitas istrumen.

Uji validitas yang dihitung dengan menggunakan program Statistical Product and Service Solutions (SPSS) dengan ketentuan kriteria pengujiannya dengan taraf signifikasi 5\% atau 0,05. Dalam penelitia ini $r$ tabel dari 25 orang responden diperoleh 0,396 dengan ketentuan jika $r$ hitung $\geq \mathrm{r}$ tabel, maka instrumen pernyataan tersebut berkorelasi terhadap skor total dinyatakan valid, jika $\mathrm{r}$ hitung < $\mathrm{r}$ tabel, maka penyataan dalam kuesioner tidak valid. Adapun hasil dari pengujian validitas didapatkan hasil sebagai berikut :

Tabel 2. Hasil Perhitungan Analisis Butir Validitas Instrumen

\begin{tabular}{ccccc}
\hline No & $\begin{array}{c}\text { No } \\
\text { Pertanyaan }\end{array}$ & r hitung & r tabel & Keterangan \\
\hline 1 & 1 & 0,784 & 0,396 & Valid \\
2 & 2 & 0,745 & 0,396 & Valid \\
3 & 3 & 0,663 & 0,396 & Valid \\
4 & 4 & 0,855 & 0,396 & Valid \\
5 & 5 & 0,646 & 0,396 & Valid \\
6 & 6 & 0,813 & 0,396 & Valid \\
7 & 7 & 0,817 & 0,396 & Valid \\
8 & 8 & 0,892 & 0,396 & Valid \\
9 & 9 & 0,826 & 0,396 & Valid \\
10 & 10 & 0,459 & 0,396 & Valid \\
11 & 11 & 0,678 & 0,396 & Valid \\
12 & 12 & 0,861 & 0,396 & Valid \\
13 & 13 & 0,797 & 0,396 & Valid \\
14 & 14 & 0,800 & 0,396 & Valid \\
15 & 15 & 0,477 & 0,396 & Valid \\
16 & 16 & 0,545 & 0,396 & Valid \\
\hline Sumber: Data Diolah, 2018 & &
\end{tabular}




\section{Uji Reliabilitas}

Pengujian reliabilitas dilakukan dengan internal consistency dengan Teknik Belah Dua (split half) yang dianalisis dengan rumus Spearman Brown.

$$
r_{i}=\frac{2 \cdot r_{b}}{1+r_{b}}
$$

Reliabilitas Instrument Implementasi pengembangan karier Aparatur Sipil Negara di Era Otonomi Daerah pada Kantor Lingkungan Hidup Kabupaten Pandeglang

$$
\begin{aligned}
r_{i} & =\frac{2 \cdot r_{b}}{1+r_{b}} \\
r_{i} & =\frac{2 \times 0.952}{1+0.952} \\
r_{i} & =\frac{1.904}{1.952} \\
r_{i} & =0.975
\end{aligned}
$$

Hasil rangkuman dari perhitungan tersebut di atas, dapat dilihat dalam tabel berikut ini :

Tabel 3. Rangkuman Hasil Perhitungan Reliabilitas Instrumen

\begin{tabular}{|llllll}
\multicolumn{1}{|c}{ Variabel } & $\begin{array}{c}\text { Koefisien } \\
\text { Korelasi } \\
\left(\mathbf{r}_{\text {tt }}\right)\end{array}$ & $\begin{array}{c}\text { Harg } \\
\left(\mathbf{r}_{\text {tot }}\right)\end{array}$ & $\mathbf{r}_{\text {tabel }}$ & Hasil \\
$\begin{array}{l}\text { Implementasi } \\
\text { Karier ASN }\end{array}$ & Pengembangan & 0.952 & 0.975 & 0.396 & Reliabel \\
\hline
\end{tabular}

Sumber : Olah Data, 2018

Dari tabel di atas dapat dilihat bahwa hasil; perhitungan reliabilitas menunjukkan bahwa semua instrumen penelitian reliabel dan dapat diandalkan.

Secara singkat deskripsi data yang dimaksudkan menyangkut skor terendah dan skor tertinggi yang secara empiris dicapai instrumen penelitian tersebut, sehingga akan nampak rentang datanya. Selain itu juga dideskripsikan variabelitas yang menyangkut nilai rata-rata (Mean), Standar Deviasi (SD).

Sebagaimana telah dikemukakan terdahulu bahwa jumlah angket yang merupakan penjabaran dari instrumen penelitian sebanyak 16 pertanyaan. Dari hasil perhitungan diketahui bahwa skor terendah 25 dan skor tertinggi 64 . Dengan demikian rentang skor yang ada adalah 39 (64-25). Bila dilihat dari angka tersebut, maka angka minimum yang mungkin dapat dicapai adalah 16 sedangkan angka maksimum yang mungkin bisa dicapai adalah 64, nilai rata-rata mencapai 46,96, dan standar deviasinya 12.413

Berdasarkan rentang skor yang ada, maka data dapat dideskripsikan ke dalam distribusi skor data instrumen penelitian tersebut secara ringkas dapat disajikan pada tabel berikut. 
Tabel 4. Distribusi Frekuensi Instrumen Penelitian



Sumber : Hasil Perhitungan SPSS, 2018

$\begin{array}{ccr}\text { Dari } & \text { data } & \text { distribusi } \\ \text { frekuensi } & \text { skor } & \text { instrumen }\end{array}$

penelitian di atas, maka dapat dibuat grafik sebaran data tersebut seperti gambar berikut :

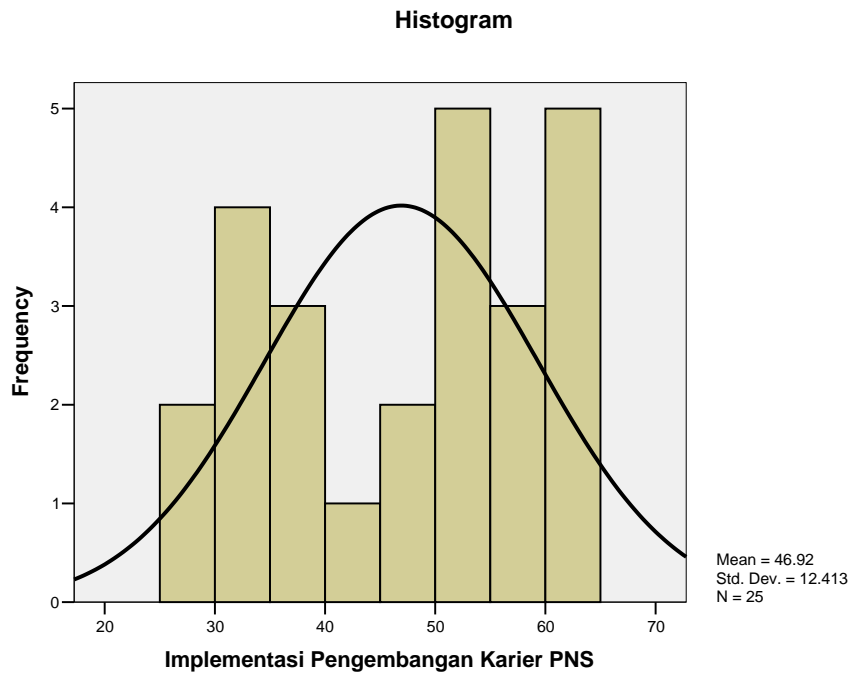

Gambar 1 : Histogram Implementasi Pengembangan Karir ASN 


\section{Uji Hipotesis}

Pengujian hipotesis dimaksudkan untuk mengetahui tingkat signifikansi dari hipotesis yang diajukan. Berdasarkan metode penelitian, pengujian hipotesis ini peneliti menggunakan rumus t-test satu sampel. Penghitungan pengujian hipotesis sebagai berikut :

Berdasarkan data yang diperoleh, maka skor ideal untuk Implementasi pengembangan karier Apratur Sipil Negara di Kantor Lingkungan Hidup Kabupaten Pandeglang adalah 4 x 25 x $16=1600$ (4 = nilai dari jawaban ideal; $25=$ jumlah responden; $16=$ jumlah pertanyaan yang ditanyakan kepada responden). Sedangkan untuk skor penelitian adalah sebesar 1173. Dengan demikian nilai Implementasi pengembangan karier Aparatur Sipil Negara di Kantor Lingkungan Hidup Kabupaten Pandeglang adalah 1173 : $1600=0,7331$ maka dalam persentase menjadi $73,31 \%$.

Implementasi pengembangan karier Aparatur Sipil Negara di Kantor Lingkungan Hidup Kabupaten Pandeglang tercapai $73,31 \%$ lebih dari yang diharapkan $70 \%$.

Selanjutnya menguji hipotesis menggunakan rumus t-test satu sampel. Skor ideal untuk Implementasi pengembangan karier Aparatur Sipil Negara pada masa otonomi daerah di Kantor Lingkungan Hidup Kabupaten Pandeglang 4 × $25 \times 16=1600$ dan nilai mean atau rata-ratanya $1600: 25=64$. Sehingga untuk Implementasi pengembangan karier Aparatur Sipil Negara pada masa otonomi daerah di Kantor Lingkungan Hidup Kabupaten Pandeglang dapat tercapai maksimal $70 \%$, hal ini berarti nilai yang dihipotesiskan $0,70 \quad$ x $64=44.8$.
Sedangkan untuk menghitung statistiknya adalah sebagai berikut : Ho untuk memprediksikan $\mu$ o lebih rendah atau sama dengan $70 \%$ dari skor ideal. Ha untuk memprediksikan no lebih besar dari $70 \%$ dari skor ideal. Ho : $\mu \mathrm{o} \leq 70 \%$ $\leq 0,70 \times 64=44.8 \mathrm{Ha}: \mu \mathrm{o}>70 \%>0,70$ $\mathrm{x} 64=44.8$. Pengujian hipotesis menggunakan rumus t-test satu sample dengan uji pihak kiri, adalah sebagai berikut :

$$
\begin{aligned}
& \mathrm{t} \quad=\frac{X-\mu_{0}}{\frac{s}{\sqrt{n}}} \\
& \text { Diketahui : } \\
& \mathrm{X}=64 \\
& \mu 0=44.8 \\
& \mathrm{~s}=12,413 \\
& \mathrm{n}=25 \\
& \text { Jadi : } \\
& \mathrm{t} \quad=\frac{X-\mu_{0}}{\frac{s}{\sqrt{n}}}=\frac{64-44.8}{\frac{12,413}{\sqrt{25}}}= \\
& \frac{19.2}{\frac{12.413}{5}}=\frac{19.2}{2.483}=7.734
\end{aligned}
$$

Harga $t$ hitung tersebut selanjutnya dibandingkan dengan harga $t$ tabel dengan derajat kebebasan $(\mathrm{dk})=\mathrm{n}-$ $1=25-1=24$ dan taraf kesalahan $5 \%$ untuk uji satu pihak kiri, maka harga $\mathrm{t}$ tabel nya yaitu 1,711. Karena harga $t$ hitung lebih besar dari pada harga t tabel $(7,734>1,711)$ dan jatuh pada daerah penerimaan $\mathrm{Ha}$, maka hipotesis nol (Ho) ditolak dan hipotesis alternatif (Ha) diterima. Harga ini dapat ditunjukan pada gambar di bawah ini dimana harga 7,734 terletak pada daerah penerimaan Ha.

Dari perhitungan populasi ditemukan bahwa Implementasi pengembangan karier Aparatur Sipil Negara pada masa otonomi daerah di 
Kantor Lingkungan Hidup Kabupaten Pandeglang adalah sebagai berikut:

Analisis Implementasi $=\frac{1173}{1600} \times 100 \%=$ 73,31
Jadi, telah diketahui bahwa analisis implementasi pengembangan karir Aparatur Sipil Negara di Kantor ngkungan Hidup Kabupaten Pandeglang adalah sebesar $73,31 \%$

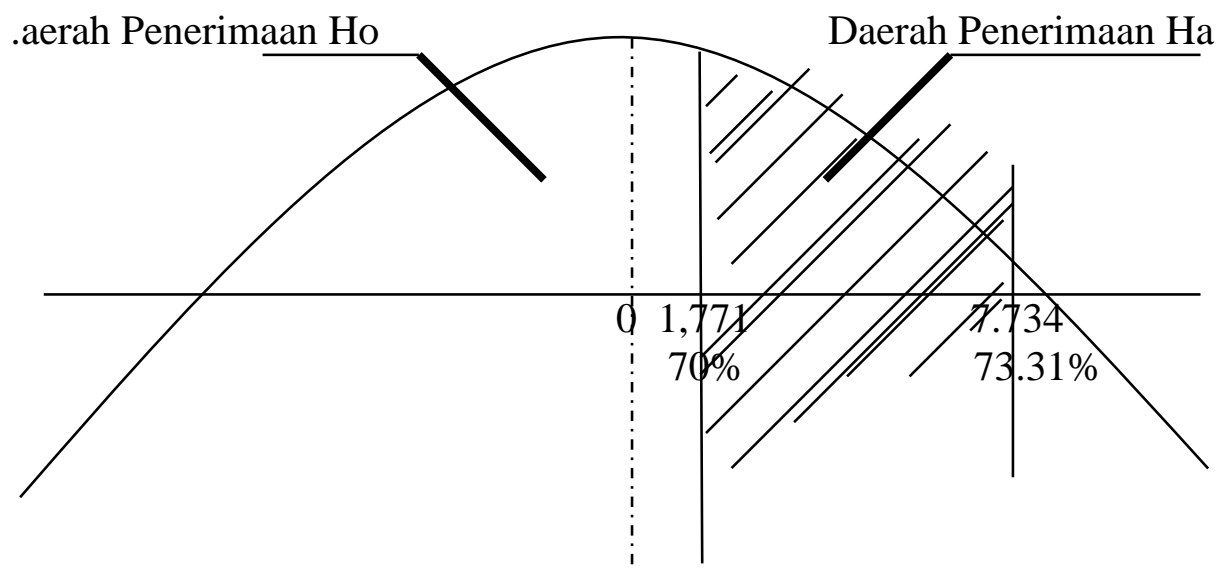

\section{Gambar 2. Kurva Penerimaan dan Penolakan Hipotesis}

Selanjutnya kita dapat mengetahui dari data skor yang diperoleh melalui jawaban responden dibagi dengan skor ideal. Hampir sama dengan perhitungan skor ideal pada pengujian hipotesis, maka berdasarkan data yang diperoleh, skor Ideal variabel adalah 4 × 25 x $16=1600$. Keterangannya adalah 4 adalah nilai tertinggi dari setiap pilihan jawaban pertanyaan yang diajukan pada responden, 25 adalah jumlah responden dan 16 adalah jumlah pertanyaan yang ditanyakan kepada responden, sedangkan untuk skor penelitian adalah sebesar 1173. Dengan demikian nilai Implementasi Pengembangan karier Aparatur Sipil Negara adalah 1173 : $1600=0,7331$ maka dalam persentase menjadi $73,31 \%$. Dari perhitungan di atas dapat peneliti simpulkan bahwa implementasi pengembangan karier Aparatur Sipil Negara Kantor
Lingkungan Hidup Kabupaten Pandeglang sudah berjalan dengan baik.

Selanjutnya seperti dalam perhitungan $\mathrm{t}$ test satu sampel bahwa implementasi pengembangan karier Aparatur Sipil Negara pada masa otonomi daerah di Kantor Lingkungan Hidup Kabupaten Pandeglang sebesar $70 \%$, namun dalam perhitungan $73,31 \%$. Artinya Implementasi pengembangan karier Aparatur Sipil Negara pada masa otonomi daerah di Kantor Lingkungan Hidup Kabupaten Pandeglang baik.

Berdasarkan hasil penelitian dan penghitungan serta pengujian hipotesis, maka dapat diketahui "Implementasi pengembangan karier Aparatur Sipil Negara di Kantor Lingkungan Hidup Kabupaten Pandeglang", tercapai 73,31\% dari maksimal $70 \%$ yang diharapkan. Pengujian hipotesis yang dilakukan berdasarkan uji hipotesis pihak kiri menunjukkan bahwa Ho ditolak dan $\mathrm{Ha}$ 
diterima, yang berarti implementasi pengembangan karier Aparatur Sipil Negara di Kantor Lingkungan Hidup Kabupaten Pandeglang adalah sudah baik dilaksanakan karena mencapai 73,31\%.

Namun dalam pelaksanaan implementasi pengembangan karier Aparatur Sipil Negara di Kantor Lingkungan Hidup Kabupaten Pandeglang ini masih ada kendalakendala yang dihadapi, peneliti melihat kepada teori yang dikemukakan oleh Siagian tentang Implementasi Pengembangan Karier yang telah dijelaskan sebelumnya. Berdasarkan hasil penghitungan kuesioner, didapatkan faktor kendala implementasi pengembangan karier Aparatur Sipil Negara, yang mengakibatkan implementasi pengembangan karier ini tidak mencapai hasil yang lebih baik lagi adalah sebagai berikut : Pertama dalam hal pengembangan sumber daya manusia, pemerintah kabupaten Pandeglang masih belum memiliki kemampuan yang cukup untuk melaksanakan program pengembangan sumber daya manusia seperti memberikan tugas belajar kepada para Aparatur Sipil Negara untuk melanjutkan pendidikan di berbagai perguruan tinggi yang ada di Indinesia, karena keterbatasan kemampuan anggaran untuk membiayai pendidikan tersebut. Dan hal ini juga dipengaruhi oleh arah kebijakan politik yang menyetujui penganggaran dana untuk biaya pendidikan bagi pengembangan sumber daya manusia. Sehingga dalam pemberian tugas belajar sangat selektif dan terbatas hanya untuk beberapa orang saja sesuai dengan anggaran dana yang tersedia. Kedua dalam hal pengembangan karier atau pengangkatan
Aparatur Sipil Negara dalam jabatan struktural, terdapat 3 (tiga) sistem: a. Sistem Patronit ( Patronage system).b. Sistem Merita ( Merit system), c. Sistem Karir ( Career system). Dari ketiga sistem tersebut di atas masingmasing memiliki kekurangan dan kelebihan yang berarti juga memberikan keuntungan dan kerugian. Begitu juga dengan Peraturan Perundang-undangan yang mengatur masalah pengangkatan Aparatur Sipil Negara dalam jabatan struktural, diantaranya pasal 1 angka 9 Peraturan Pemerintah Republik Indonesia Nomor 100 Tahun 2000 yang menyatakan, Pola karir adalah pola pembinaan Aparatur Sipil Negara yang menggambarkan alur pengembangan karir yang menunjukkan keterkaitan dan keserasian antara jabatan, pangkat, pendidikan dan pelatihan jabatan, kompetensi, serta masa jabatan seorang Aparatur Sipil Negara sejak pengangkatan pertama dalam jabatan tertentu sampai dengan pensiun.

Dari penjelasan pasal 1 angka 9 Peraturan Pemerintah Republik Indonesia Nomor 100 Tahun 2000 tersebut tidak menunjukkan batasan-batasan yang tegas mengenai tingkat pendidikan yang dapat menduduki suatu jenjang jabatan struktural, sehingga dalam praktek bisa saja terjadi orang yang memiliki tingkat pendidikan yang lebih rendah menduduki jenjang jabatan yang lebih tinggi walaupun pangkat atau golongannya sama. Dan hal ini selalu ditemukan alasan-alasan yang tepat seandainya ada pertanyaan mengapa menempatkan orang yang pendidikan atau pangkatnya lebih rendah pada suatu jenjang jabatan yang lebih tinggi. Hal ini karena banyaknya kriteria yang dapat dipilih sebagai alasan 
menempatkan seseorang pada suatu jabatan tertentu, tergantung selera dan kepentingan pejabat atasan yang akan memakai tenaga seseorang pegawai.

Kendala-kendala lain dalam hal pengangkatan Aparatur Sipil Negara dalam jabatan struktural yaitu adanya pegawai titipan dari seseorang pejabat yang biasanya mendapatkan perlakuan khusus untuk mendapatkan suatu jabatan. Jadi, implementasi pengembangan karier Aparatur Sipil Negara di Kantor Lingkungan Hidup Kabupaten Pandeglang sampai saat ini belum berjalan maksimal, hal ini dikarenakan beberapa faktor penghambat yang telah diuraikan diatas. Akan tetapi, hal tersebut dapat dihindari apabila didorong oleh kesadaran sumber daya yang terlibat didalamnya agar patuh pada prosedur yang ada yang telah ditetapkan dalam perundang-undangan. Suatu program yang telah diundangkan dan diimplementasikan membutuhkan aparataparat yang sesuai dan berkualitas, sehingga program yang telah ditetapkan akan dilaksanakan dengan baik sesuai dengan ketentuan yang telah ditetapkan.

\section{PENUTUP}

\section{SIMPULAN DAN SARAN}

Berdasarkan hasil penelitian yang telah dilakukan dapat menarik kesimpulan : Pertama implementasi pengembangan karier Aparatur Sipil Negara di kantor Lingkungan Hidup Kabupaten Pandeglang sudah mencapai angka $73,31 \%$ melebihi angka yang diharapkan yakni 70\%.. Kedua berdasarkan hasil pengujian hipotesis dengan uji t-test satu sample diperoleh harga $t_{\text {hitung }}$ lebih besar dari pada harga $t_{\text {tabel }}(7,734>1,711)$, Dengan demikian maka hipotesis nol (Ho) yang penulis ajukan ditolak dan hipotesis alternatif (Ha) yang penulis ajukan diterima.

Adapun saran yang diajukan adalah : Pertama pimpinan kantor Lingkungan Hidup Kabupaten Pandeglang, perlu menetapkan aturan atau pedoman tentang pengembangan karier yang jelas dan diimplementasikan secara benar terhadap seluruh pegawai. Peraturan pembinaan karier hendaknya mengedepankan hak, kewajiban dan peluang yang sama bagi seluruh pegawai. Perlu adanya perlakuan yang adil terhadap seluruh pegawai dan kriteria promosi didasarkan pada pertimbangan yang objektif, rasional dan diketahui secara luas di kalangan pegawai. Selain itu perlu adanya keterlibatan atasan langsung dalam perencanaan karier dan memberikan umpan balik pada para pegawai tentang pelaksanaan tugas masing-masing sehingga para pegawai mengetahui potensi yang perlu dikembangkan dan kelemahan yang perlu diatasi. Kedua pimpinan kantor Lingkungan Hidup Kabupaten Pandeglang hendaknya lebih memperhatikan perkembangan dan intensitas tuntutan keterbukaan dan demokratisasi serta menjamin kepastian arah pengembangan karier pegawai melalui peningkatan kemampuan dengan memberikan pendidikan dan pelatihan yang baik dan berkualitas sehingga tercipta pegawai yang mempunyai kemampuan sesuai kebutuhan organisasi dalam menyelaraskan dirinya dengan perkembangan dinamika masyarakat. Selain itu perlu adanya pemetaan rencana-rencana pendidikan dan pelatihan baik jenis, macam dan tingkatannya agar terciptanya pegawai 
Kantor Lingkungan Hidup Kabupaten Pandeglang yang unggul dan berkompetensi dalam melaksanakan tugas.

\section{DAFTAR PUSTAKA}

Alwi, Syafaruddin, 2001, Manajemen Sumber Daya Manusia, Strategi Keunggulan Kompetitif, Edisi Pertama, Penerbit BPFE, Yogyakarta.

Ghozali, Imam, 2001, Aplikasi Analisis Multivarite Dengan Program SPSS, Edisi Ketiga, Penerbit Badan Penerbit Universitas Diponegoro, Semarang.

Gibson, James L, at all, 2004, Organisasi, Perilaku, Struktur, Proses, Jilid Kedua, Penerbit Erlangga, Jakarta.

Handoko., 2008, Manajemen Personalia dan Sumber Daya Manusia (edisi 2). Yogyakarta: BPFE.

Hasibuan, Malayu SP, 2009, Manajemen Sumber Daya Manusia Edisi Revisi, Penerbit Bumi Aksara Jakarta

Kuncoro, Mudrajad, 2003, Metode Riset Untuk Bisnis Dan Ekonomi, Penerbit Erlangga, Jakarta.

Mangkunegara, A.A.Prabu, 2000, Manajemen Sumber Daya Manusia Perusahaan, Penerbit Rosda Karya, Bandung.
Manullang. M., 2001 Dasar-dasar Manajemen., Ghalia Indonesia. Jakarta

Mas'ud Moh., 2000 Manajemen Sumber Daya Manusia Perusahaan. Alfabet. Bandung

Moekijat, 2005, Manajemen Kepegawaian, Penerbit Alumni, Bandung.

Nasution, Harmein, 2005, Proses Pengelolaan Sumber Daya Manusia, USU Press, Medan.

Nawawi, Hadari , 2010, Manajemen Sumber Daya Manusia Untuk Bisnis Yang Kompetitif, Cetakan Keempat, Penerbit Gadjah Mada University Press, Yogyakarta.

Rivai, Veithzal, 2004, Manajemen Sumber Daya Manusia Untuk Perusahaan, PT.Raja Grafindo Persada, Jakarta

Santoso, Singgih, 2001, SPSS , Mengolah Data Statistik Secara Proversional, Cetakan Keempat, Penerbit PT Elex Media Komputindo, Jakarta.

Siagian Sondang P, 2004 Pengembangan Sumberdaya Manusia, Teori dan Praktek, Jakarta, Bumi Aksara

Siagian Sondang P, 2007 Teori Pengembangan Organisasi, Jakarta, Bumi Aksara 
Simamora, Hendry, 2008, Manajemen Sumber Daya Manusia, Edisi Kesatu, Cetakan Pertama. Badan Penerbit STIE, Yogyakarta.

Singarimbun, Masri dan Sofian, 1995, Metode Penelitian Survey, Cetakan Kedua,Penerbit PT Pustaka LP3ES Indonesia, Jakarta.

Sodjadi, FX., 2006 Manajemen Sumber Daya Manusia, Rineka Cipta. Jakarta

Soeprihanto, John, 2001, Penilaian Kinerja dan Pengembangan Karyawan, Penerbit University Press, Yogyakarta.
Sugiyono, 2004, Statistika Untuk Penelitian, Cetakan Keenam, Penerbit Alfabeta,Bandung.

Thoha, Miftah, 2002, Perilaku Organisasi, Fisipol Universitas Gajah Mada,Penerbit PT Raja Grafindo Persada, Jakarta.

Umar, Husein, 2002, Metode Riset Bisnis, Cetakan Pertama, Penerbit PT.Gramedia, Jakarta

Undang-Undang Nomor 43 Tahun 1999 tentang Pokok-pokok Kepegawaian

Peraturan Pemerintah Republik Indonesia Nomor 100 Tahun 2000 tentang Pengangkatan Pegawai Negeri Sipil 